\title{
Regional policies and eco-industrial development: the voluntary environmental certification scheme of the eco-industrial parks in Tuscany (Italy)
}

\author{
Tiberio Daddi ${ }^{\mathrm{a}, ~}{ }^{*}$, Fabio Iraldo ${ }^{\mathrm{a}}$, Marco Frey ${ }^{\mathrm{a}}$, Paola Gallo ${ }^{\mathrm{b}}$, Valentina Gianfrate ${ }^{\mathrm{c}}$ \\ a Institute of Management, Sant'Anna School of Advanced Studies, Piazza Martiri della Libertà, 33, 56127 Pisa, Italy \\ b School of Architecture, Department DIDA, University of Florence, Via San Niccolò, 893, 50125 Firenze, Italy

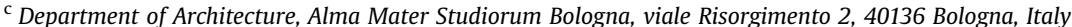

\section{A R T I C L E I N F O}

\section{Article history:}

Received 15 July 2014

Received in revised form

16 March 2015

Accepted 17 April 2015

Available online 28 April 2015

\section{Keywords:}

Eco-industrial park (EIP)

Industrial symbiosis

Voluntary environmental certification

Environmental policy

\begin{abstract}
A B S T R A C T
Industrial ecology is presented in the literature as both a policy tool and an academic theory. This paper discusses a voluntary certification scheme adopted by the regional government of Tuscany (Italy) as a policy tool to disseminate the concepts of industrial ecology. The approval of a regional regulation represents the first adoption in European environmental and industrial policies of a voluntary tool aimed at stimulating the creation and dissemination of eco-industrial parks. This new certification method is analysed by focusing on the prevention of pollution. The criteria required to obtain the qualification, and the roles and responsibilities of all the actors involved are outlined. Finally, the strengths and weaknesses of the certification scheme are highlighted and the Italian standard compared with the national standard issued in China by the State Environmental Protection Administration. The findings contribute to the discussion of policy measures aimed at disseminating the concepts of Industrial Ecology including a tool based on voluntary co-operation and third-party certifications.
\end{abstract}

() 2015 Elsevier Ltd. All rights reserved.

\section{Introduction}

Industrial ecology (IE) theory has mainly been developed by drawing on natural science and engineering-oriented frameworks (Korhonen and Strachan, 2004). Early analyses of IE focused on the physical flows of materials and energy within industrial systems, with less emphasis on the development of policy mechanisms (Opoku, 2004). This is confirmed by one of the most cited definitions of industrial symbiosis (IS), one of the key concepts of IE: "IS engages traditionally separate industries in a collective approach to competitive advantage involving physical exchange of materials, energy, water and by-products" (Chertow, 2000).

The definition of IS has since been reinterpreted, for example Lombardi and Laybourn (2012) define IS as a tool to spread innovative green growth by fostering "eco-innovation and long-term cultural change".

Also the importance of policy action to support the spread of IE concepts has been revised. Lombardi et al. (2012) highlight how IS

\footnotetext{
* Corresponding author. Tel.: +39 050883936.

E-mail address: tiberio.daddi@sssup.it (T. Daddi).
}

has been documented in six continents at all policy levels (international, national, regional and local) as "a strategic policy tool for economic development, green growth, innovation and resource efficiency". Yu et al. (2014) studied research in the field of IS in the period 1997-2012. The study reveals the evolution of IS from practice-oriented research toward more systematic and diverse topics. The analysis confirms the main findings of Lombardi et al. (2012) and classifies the domain of IS into five main themes: wastewater treatment and management; energy efficiency; solid waste management; self-organization of IS systems; and policy making and evaluation for IS and eco-industrial park (EIP) projects. The importance of IE policy implications is emphasized by Von Malmborg (2004) who claims that most studies on industrial ecology in practice "seem to ignore the roles of governments in facilitating (or obstructing) industrial ecosystem development". He invites other authors to contribute to this topic and confirms that "policies and actions taken by governments and public authorities on different levels constitute important institutional settings for the development of industrial ecosystems". Lehtoranta et al. (2011) argue that few studies exist on the overall impact of policy instruments aimed at promoting the design of eco-industrial parks. In addition, this literature highlights how both policies and practical 
experience are also still too focused on the reuse and recycling of materials rather than the implementation of pollution prevention at the park level (Geng et al., 2012).

In recent years several articles have thus been published on the policy implications of IE (Geng et al., 2009; Mirata, 2004). In the described literature framework, this paper aims to contribute to this topic by describing an innovative policy initiative in Italy based on pollution prevention in order to stimulate, support and coordinate the diffusion of eco-industrial parks.

Section 3 describes a voluntary certification scheme adopted by the regional government of Tuscany as a policy tool to disseminate IE concepts. The scheme follows a "holistic" method, which has strong links with voluntary policy tools. This "holistic vision" emphasizes the need for an innovative and co-operative approach to local development, based on voluntary, public-private partnerships and on the ability to collaboratively manage economic objectives, with the approval of local communities. Many studies carried out in the last decade in Italy have provided evidence that a holistic approach, based on co-operation between economic, social and institutional actors and on bottom-up local policy making, yields better results for the area, both in environmental and competitive terms (Daddi et al., 2012).

Section 4.1 compares the Tuscan standard and a similar certification standard approved by the Chinese State Environmental Protection Administration. The goal is to identify the common elements that are both "holistic" and are based on a voluntary approach. The building blocks of an innovative stream of policies inspired by IE can thus be identified. This comparison also highlights the relative weaknesses that must be overcome when implementing such an approach in other contexts. This means that it can be verified whether such weaknesses are specific to a particular national institutional and policy framework or whether they are likely to be true in all cases.

\section{Policy approaches to industrial ecology concepts}

The concepts of IE and IS find their concrete applications in the creation and development of EIPs. One of the most well-known definitions of an EIP was provided by the United States Environmental Protection Agency (Martin et al., 1996): "a community of manufacturing and service businesses seeking enhanced environmental and economic performance by collaborating in the management of environmental and reuse issues. By working together the community of businesses seeks a collective benefit that is greater than the sum of the individual benefits each company would realise if it optimised its individual performance only".

The aim is to maximise the use of co-products and by-products, whilst reducing the residual products of the processes (Zhu and Cote, 2004). The definition of EIP has since gone beyond the strict connection with the concept of by-product transfer. It has been enriched by other elements such as EIP networks (Gibbs and Deutz, 2007), management issues (Mirata, 2004), and utility sharing and joint service provision (Chertow et al., 2008).

At an international level, different approaches have been adopted by policy makers to apply the industrial ecology principles and support the dissemination of EIPs. As a policy concept, industrial ecology has informed a variety of practical initiatives, particularly through the promotion and development of EIPs. Korhonen et al. (2004) discussed how industrial ecology can be a bridge from "the descriptive analysis of materials and energy flows in industrial systems toward a prescriptive framework offering concrete solutions and practical measures for policy makers and business managers".

The policies adopted to disseminate EIPs can be categorized according to two main types of environmental approaches: 1. direct regulation (also known as 'command and control'), and economic instruments (especially financial subsidies); 2 . voluntary tools.

Direct regulation and economic instruments seem to be preferred by governments, while local authorities are more likely to adopt voluntary tools. Direct regulation and economic instruments have been applied in many countries in Europe (Eilering and Vermeulen, 2004; Heeres et al., 2004), North America (CohenRosenthal, 1996; Hendricks and Giannini-Spohn, 2003) and Asia (Geng and Doberstein, 2008; Shi et al., 2010; Zhang a et al., 2010) to promote specific eco-industrial initiatives.

Lehtoranta et al. (2011) report how Finland does not have direct policy instruments to promote IE concepts although the development of some EIPs has been encouraged using other political instruments. The authors identify tax relief for the use of by-products as a possible tool for resource efficiency. In addition, the authors consider a stronger taxation of transport and fuels as well as limiting end-of-pipe emissions through environmental permits as an indirect means to promote the development of EIPs.

Stricter legislation or economic policies aimed at promoting the spread of EIPs are also common in Asia. For example, the development of industrial symbiosis in Ulsan city, the main industrial city of South Korea, was promoted by direct regulation initiatives consisting in strict legislation and environmental standards (Park et al., 2008). In China's Tianjin industrial development, local subsidies for high-quality infrastructure stimulated the development of a high number of symbiotic relationships. Shi et al. (2010) identified 81 cases of industrial symbiosis in this industrial area supported with this economic instrument.

Nevertheless, some authors argue that in order to implement IE concepts, "combinations of active governmental policy and voluntary and proactive actions by private firms are needed" (Korhonen et al., 2004).

Voluntary tools are adopted less often to implement IE concepts and are discussed minimally in the literature regarding the policy approaches linked with IE (Tudor et al., 2007; Gibbs and Deutz, 2007). In addition, very few studies are related to policies that involve issuing voluntary certifications to reward the environmental development of the areas. Despite this, in other fields of the application of Sustainable Consumption and Production policies, these instruments have proved effective in enhancing both environmental and economic performance in industrial companies (Iraldo et al., 2009; Daddi et al., 2011) as well as in the public administration (Daddi et al., 2013).

Costa et al. (2010) investigate the different waste policy interventions as a leverage to spread IS initiatives in Denmark, the UK, Portugal and Switzerland. Denmark opted for the strict use of regulatory and economic instruments, while the UK, Portugal and Switzerland applied a mix of policy tools including voluntary instruments.

Sanches Pereira et al. (2009) describe the current "command and control" approach used by policy makers in Brazil. They argue for an evolution of Brazil's IE policies from "command and control" to "command and covenant" based on shared responsibility, shared membership and shared decision making among governments and corporations. They suggest that the new approach would help create a system with higher eco-innovation and competitiveness.

Tudor et al. (2007) identify the main drivers and limitations for the successful development of EIPs. They list a group of measures to enhance the success of EIPs and point out the need for a voluntary initiative to better implement the IE principles: "the initiative should come from the firms and not from government".

By analyzing public-private partnerships in Sweden, Von Malmborg (2004) shows that local authorities use their policy instruments to act as "knowledge banks" or "knowledge brokers". As "knowledge banks", local authorities hold the knowledge that is 
transferred to companies and they engage closely with the companies in small active networks. As "knowledge brokers", local authorities are less active and mainly help companies to get in contact with consultants and technical experts who hold the knowledge needed to develop environmental management in the companies.

Mirata (2004) illustrates the National Industrial Symbiosis Program (NISP) launched in three regions of UK. The program was part of a policy initiative of the Business Council for Sustainable Development; based on the prevention of pollution principle aimed at spreading IE concepts among the industrial areas of the three regions.

Park et al. (2008) focus on Korean policies to support EIPs. They describe the use of a mixed policy initiative (including financial support) to improve the existing environmental infrastructure, to facilitate technology transfer, and promote environmental management systems at the firm level.

Van Berkel et al. (2009) describe a successful voluntary program launched by the Japanese Government. This was named Eco-town and was aimed at spreading industrial symbiosis to industrial areas located in proximity to urban areas. Essentially, it provided financial subsidies to the local authorities to develop EIPs or contributed to improvements in the planning of the town and the industrial areas.

According to Gibbs and Deutz (2007), public intervention should aim to facilitate voluntary co-operation between the firms located in the EIPs in order to achieve economic benefits. The policies should help companies to identify these opportunities by creating the "appropriate conditions for inter-firm networking to take place." In such cases, "local authorities could serve as network brokers and "institutional anchor tenants," initiating the actor networks and providing political and managerial support as well as informational and educational services and infrastructure support for the other participants in the industrial ecosystem" (Korhonen et al., 2004).

\section{The certification scheme of the region of Tuscany}

In 1998 an Italian national law (decree 112/98) introduced the concept of Ecologically Equipped Industrial Areas known in Italian as APEAs. In December 2009, Tuscany, which is one of the Italian regions that is most engaged with the IE approach as a policy tool, launched a new initiative that sparked an innovative policy stream based on the voluntary approach. The new regional law known as Tuscan Regulation 74/2009 (Regione Toscana, 2009a) and Resolution 1245/2009 (Regione Toscana, 2009b) established the scheme and the criteria to enable the EIPs to voluntarily achieve APEA certification. This certification standard is fully managed at the regional level, central government does not play any role in managing the scheme or in boosting the dissemination of EIPs.

The criteria were drafted and approved through the involvement of a group of experts. The authors of this article were part of this group and contributed to defining the criteria that represent the first public standard for EIPs in Italy and Europe. The legislative acts mentioned above were specifically aimed at spreading the concepts of eco-industrial development in Tuscany. This is the first time that a legislation in Tuscany has attempted to incentivize local policy makers to plan new or to reconvert existing industrial parks in a more sustainable way. In any case, the aforementioned regional legislative acts are part of a framework of regional policies aimed at the spread of EIPs. The Regional Environmental and Energy Plan (Regione Toscana, 2014), which is the main important regional plan in the field of sustainable development, identifies eco-industrial policies and the APEA as key issues to pursue. In addition the current draft of the law for the "government of the territory" (which will be published in 2015) contains important references to the APEA confirming the availability of public funds to spread APEA certification in the near future. In the Tuscan certification scheme defined by Regional Regulation 74/2009 the management body (MB) plays a prominent role. The MB is generally a mixed publicprivate company, which covers a range of roles and functions within the APEAs.

With regards to IE, the MB is a "facilitator" in the area, in order to activate and support specific measures that are essential for the success of EIPs, such as the proactive participation of private and public stakeholders, cooperation among local firms, and regular monitoring of the environmental goals and program to be achieved.

The regional government supervises the appropriate implementation of the certification scheme and carries out spot checks in certified areas to ensure compliance with the criteria established by the regional law. The provincial governments aim to guarantee territorial coordination and efficient and effective use of land. Municipalities have various functions in the APEA system: they choose the location, identify the $\mathrm{MB}$ and verify the compliance of the area with the APEA certification criteria.

A key issue is the engagement of local companies. The standard requires the $M B$ to sign an agreement with all of them. The agreement is required to define some of the companies' duties such as actively participating in the implementation of the relevant criteria, contributing to the initiatives of the MB for the improvement of environmental management in the area, and authorizing the MB to represent them in the marketing in the local area. The involvement of companies is a key issue in Tuscan EIPs as in many other EIPs. To incentivize companies to take part in the MB, various initiatives have been carried out, for example reducing municipal taxes (e.g. the tax on urban waste) for those companies that sign the agreement.

The system is thus likely to impact on the main industrial sectors of Tuscany. In particular, if the added value for 2011 is used as an indicator, the most important of manufacturing sectors in Tuscany are paper production, tanneries, textiles, machinery and wood/furnishings In terms of exports, the most important sectors are jewelry, leather goods and shoes, which represent $37 \%, 34 \%$ and $21 \%$, respectively, of Italian exports (IRPET and Unioncamere Toscana, 2013). The geographical distribution and the size of the companies could also increase the expected impact of APEA legislation on these three sectors. The sectors are characterized by a large presence of micro and small and medium enterprises (SMEs), which are often grouped into industrial clusters or into sectorspecific industrial areas.

\subsection{The criteria for certification}

According to resolution $1245 / 2009$, certification criteria are classified into minimum requirements and flexible requirements. Minimum requirements are divided into three classes: urban and planning criteria, infrastructural criteria and management criteria. Both classes of requirements are part of the certification scheme that represents Tuscany's voluntary tool for the implementation of IE concepts. The criteria are applied in a different way to existing or new areas as shown in Fig. 1.

\subsubsection{Minimum requirements}

The first class of criteria established by the regional regulation relate to the urban characteristics of EIPs that must seek certification. Each criterion outlines either qualitative characteristics or quantitative indicators with which to comply. The purpose of the infrastructural criteria is to establish requirements that aim to supply industrial facilities with the infrastructure capable of achieving high environmental performance and economic benefits. 


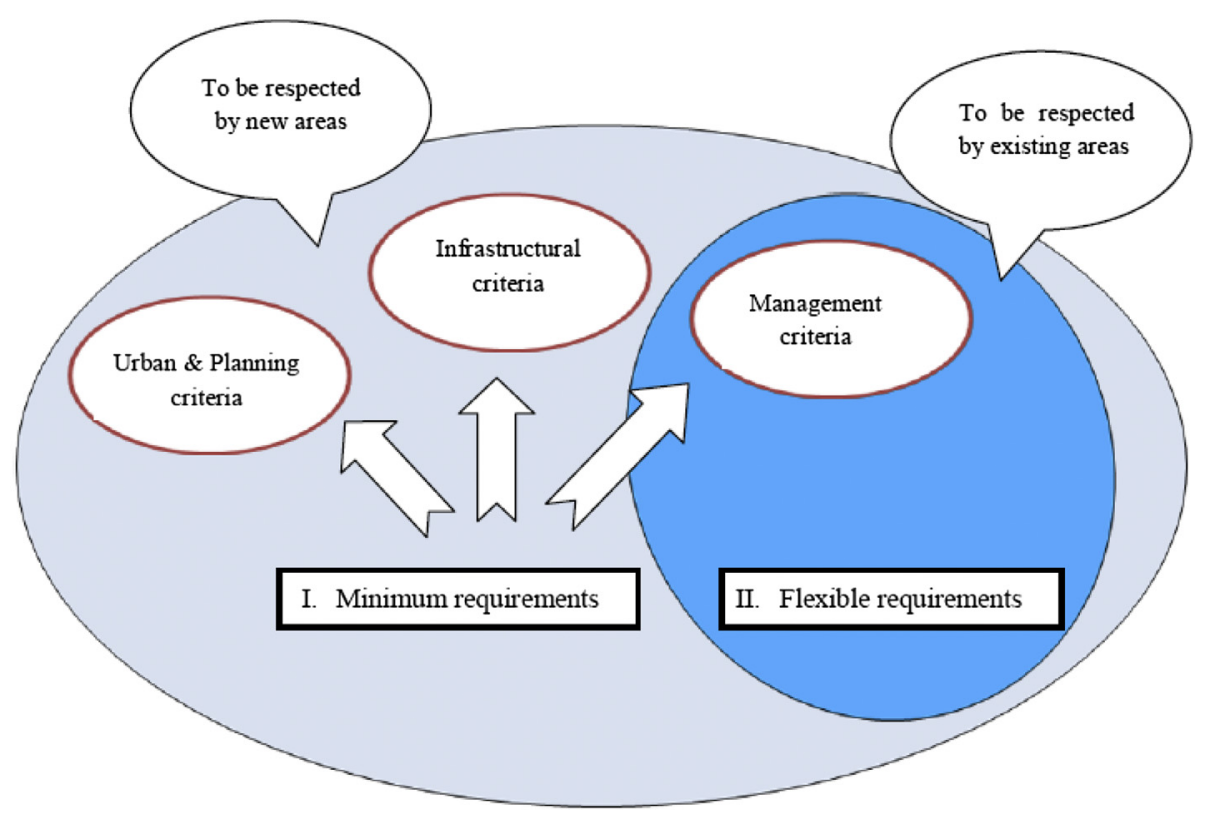

Fig. 1. Certification requirements applicable to new and existing industrial areas.

There are eight criteria that specify management requirements related to several environmental issues (see Table 1 ).

Table 1 highlights the criteria related to the visual impact of industrial areas (criteria 7, 8 and 9). Tuscany is one of the most beautiful regions in Italy. Its landscapes are unique and attract many tourists throughout the year. Tuscan landscapes facilitate the economic development of the countryside especially through the agro-tourism sector. Therefore the regional government is attempting to avoid certifying industrial areas that are not integrated within the landscape.

In the next Table 2 the infrastructural criteria are highlighted.

A key infrastructural point in Criteria 11-19 is water management relating to both water consumption and water emissions. Many Italian areas lack drinkable water during the summer if the weather is particularly dry. Criterion 11 regards a system to improve the efficiency of the industrial area in water use. Uses such as firefighting systems, irrigation of green areas, and toilets can easily be fed with recovered rain water. Criterion 13 imposes the installation of a common purification system for industrial waste water emissions thus facilitating better management of water emissions plus economic savings for the companies located in the area. Finally the next Table 3 describes the minimum management criteria to be satisfied.

As shown in Fig. 1, all the criteria listed in Tables 1-3 must be respected by both new and existing industrial areas. Tuscany's certification scheme gives an important role to the MB, and Criteria 21-27 describe the main roles of the MB in the management of the industrial area to be certified.

To ensure that all areas apply the criteria in the same way, the regional government has published official guidelines that explain how the areas must implement the requirements. The criteria listed in Tables $1-3$ are not the only requirements to be satisfied, there are also additional managerial requirements that both existing and new industrial areas must meet. The regional administration in Tuscany was inspired by experiences of environmental management of even larger areas such as industrial clusters of.

SMEs in Italy and the rest of Europe (Ammenberg and Hjelm, 2003; Daddi et al., 2010) and by the Regional Environmental

Table 1

Minimum urban and planning criteria (1-10) present in the Resolution 1245/2009.

\begin{tabular}{|c|c|c|}
\hline No. & Criteria & Description \\
\hline 1 & Sustainable mobility infrastructures & $\begin{array}{l}\text { Specific materials must be used for building roads, such as sound-absorbing asphalt. There should be a hierarchy } \\
\text { of traffic, pedestrian and bicycle flows in order to reduce the environmental impact of traffic and improve safety. }\end{array}$ \\
\hline 2 & $\begin{array}{l}\text { Green system and ecological } \\
\text { network connection }\end{array}$ & $\begin{array}{l}\text { Using native species in the establishment of green areas, } 70 \% \text { of roads must be bordered by tall trees; hedges } \\
\text { and trees in parking areas; ecological corridors to integrate any ecological networks already present. }\end{array}$ \\
\hline 3 & Soil permeability & $\begin{array}{l}\text { The surface of private land not occupied by buildings must be at least } 25 \% \text { permeable. The surfaces of public } \\
\text { parking areas must be at least } 70 \% \text { permeable. Bicycle and pedestrian paths should be made of } \\
\text { draining materials. }\end{array}$ \\
\hline 4 & Underground facilities network & Aqueducts, power grids, telecommunications networks, etc. must be built in order to facilitate maintenance. \\
\hline 5 & Communication networks & The area must have advanced telecommunication systems. \\
\hline 6 & Lighting of public areas & $\begin{array}{l}\text { Light bulbs with a colour rendering index }>65 \text { and an efficiency of at least } 90 \text { lumens/watt must be used along } \\
\text { with measures to reduce light pollution. } 50 \% \text { of the power for lighting public roads and parking areas must } \\
\text { come from renewable sources. }\end{array}$ \\
\hline 7 & Optimizing the visual aspect & $\begin{array}{l}\text { Along the borders of the EEIAs there should be a strip of at least } 10 \mathrm{~m} \text { wide made up of tall trees of } \\
\text { native species. }\end{array}$ \\
\hline 8 & Landscape integration & Buildings and spaces in the area must be integrated into the natural landscape. \\
\hline 9 & Colour planning & The colours of the buildings must be regulated. \\
\hline 10 & Energy efficiency & $\begin{array}{l}\text { Fixed or mobile screening systems must be used for south-facing transparent surfaces. Areas and buildings } \\
\text { must be laid out to maximize the exploitation of solar radiation. }\end{array}$ \\
\hline
\end{tabular}


Table 2

Minimum infrastructural criteria (11-19) present in the Resolution 1245/2009.

\begin{tabular}{|c|c|c|}
\hline No. & Criteria & Description \\
\hline 11 & Collection and reuse of rainwater & $\begin{array}{l}\text { Collection of at least } 50 \% \text { of rainwater fallen on impermeable surfaces (e.g. roofs, streets, etc). At least } 80 \% \text { of collected } \\
\text { water must be reused in industrial facilities, for domestic use, in the fire fighting system or to irrigate the green areas. } \\
\text { A double system for the distribution of water must be implemented in the area: one for drinkable water, the second } \\
\text { for collecting rainwater. }\end{array}$ \\
\hline 12 & Separate sewer systems & $\begin{array}{l}\text { The area sewage system should include industrial wastewater piping and polluted rainwater piping; domestic } \\
\text { wastewater piping, non polluted rainwater piping. }\end{array}$ \\
\hline 13 & Treatment of industrial water & The industrial wastewater sewage system must have a single purification system and a single discharge. \\
\hline 14 & Use of renewable energies & $\begin{array}{l}\text { The area should comply with at least one of the following: a) surface covered with solar or photovoltaic panels }>15 \% \text {; b) } \\
\text { electric } \mathrm{kW} \text { installed for each hectare of surface } \geq 105 ; \mathrm{c} \text { ) thermal } \mathrm{kW} \text { installed for each hectare of surface } \geq 315 \text {. }\end{array}$ \\
\hline 15 & Sustainable mobility measures & $\begin{array}{l}\text { At least one of the following requirements must be met: a) multiple bus stops, b) bicycle paths covering at least } 40 \% \\
\text { of the length of the roads in the area; c) a service center (restaurants, meeting room, offices, etc.). }\end{array}$ \\
\hline 16 & Advanced logistic measures & $\begin{array}{l}\text { At least one of the following requirements must be met: a) a centre for sorting goods, warehousing, storage and } \\
\text { distribution; b) infrastructures for the application of "Integrated Logistics". }\end{array}$ \\
\hline 17 & $\begin{array}{l}\text { Fire prevention equipment } \\
\text { and measures }\end{array}$ & $\begin{array}{l}\text { A shared fire fighting system (with fire hydrants or other aids) activated by the firefighters in the case of fire, as a } \\
\text { safeguard in addition to those required by the law and already present in the enterprises. }\end{array}$ \\
\hline 18 & Mobility security measures & $\begin{array}{l}\text { Raised pavements to separate roads from pedestrian/bicycle paths. Speed-reducing devices. Safe intersections and } \\
\text { pedestrian/bicycle crossings. }\end{array}$ \\
\hline 19 & Washing area for trucks & Areas over 20 ha must have on-site truck washing facilities. \\
\hline
\end{tabular}

Management System - REMS (Snaekin and Korhonen, 2002; Niutanen and Korhonen, 2003; Welford, 2004). Based on these experiences, the Tuscan regulation requires that the MB must:

- perform an "Environmental Analysis of the Productive Context" to highlight the situation of the environment surrounding the industrial area, and the main environmental pressures exerted by the productive sectors settled in the area.

- define an environmental policy that lists the overall principles and mission of its environmental management of the APEA;

- establish a Program for the Environmental Improvement of the area which should take into account the results of the Environmental Analysis. The goals in the Program must match quantified targets, the actions needed to achieve them, deadlines, resources and actors involved in charge of implementing the actions.

The requirements listed in Table 4 that enable the Management Body to get APEA certification are also in line with ISO14001 standards which are applied at an industrial and park level as if the park was a single manufacturing plant (Geng and Côté, 2003).

\subsubsection{Flexible requirements}

In addition to the class of minimum requirements, Resolution $1245 / 2009$ provides for a class of flexible requirements. Flexible requirements are so named because the industrial areas requesting APEA certification are able to choose the criteria from a list of 78 different requirements. These 78 requirements are classified according to different classes: water management (11 criteria), energy (15) waste management (9), mobility and logistics (10), habitat and landscape (6), health and safety (7), prevention of pollution (7), various (13).

The Regional Regulation 74/2009 assigns a score to each criterion. Depending on the relevance of the criterion, the score varies from a minimum of 1 to a maximum of 5 . The total number of scores assigned to the 78 criteria is 278 . The existing or new areas that want to achieve APEA certification must show compliance with the flexible requirements by obtaining a score of at least 100 (choosing freely from the listed criteria). The Table 5 shows an example of the flexible criteria and their scores relating to "water management".

Unlike the minimum requirements, flexible requirements are not divided into urban, infrastructural and management categories: they are only divided according to environmental issues.

\section{Discussion: strengths and weaknesses}

For the first time in Europe a voluntary certification process for industrial areas has been established, based on requirements and mechanisms set by a regulation adopted and managed by a public entity. The requirements and the criteria are strongly based on a

Table 3

Minimum management criteria (21-27) present in the Resolution 1245/2009.

\begin{tabular}{|c|c|c|}
\hline No. & Criteria & Description \\
\hline 20 & Water consumption monitoring systems & $\begin{array}{l}\text { The MB must provide evidence of having established a system designed to monitor the needs and the } \\
\text { water withdrawals of the industrial area, with specific reference to withdrawals made from ground water. } \\
\text { Based on these data, the MB should promote water saving actions among local companies. }\end{array}$ \\
\hline 21 & Energy management and monitoring & $\begin{array}{l}\text { An Energy Manager should be appointed for the area to monitor energy consumption and coordinate } \\
\text { energy saving and the dissemination of renewable sources. }\end{array}$ \\
\hline 22 & Waste area management & $\begin{array}{l}\text { It envisages: a) a Waste Management Plan; b) total or partial recycling of materials used and produced } \\
\text { in the area; c) a list of common providers of transportation and waste disposal, selected on the basis of } \\
\text { environmental requirements. }\end{array}$ \\
\hline 23 & Mobility Management & $\begin{array}{l}\text { At least one of the following must be implemented: a) at least one ecological means of transportation for } \\
\text { the operators; b) reasonable fares for public transport; c) car pooling; d) car sharing. }\end{array}$ \\
\hline 24 & Logistic Management & Van pooling. \\
\hline 25 & Emergency response plan & $\begin{array}{l}\text { An emergency response plan that illustrates how companies should react and the actions to be taken } \\
\text { outside the industrial area. }\end{array}$ \\
\hline 26 & Sustainable management of green areas & Green areas managed in terms of biodiversity protection, landscape conservation, and carbon fixing \\
\hline 27 & Sustainable management of construction sites & $\begin{array}{l}\text { A plan to minimize the environmental impacts of site operations. The plan must identify all the operations } \\
\text { that could create environmental criticalities, and highlight responsibilities and operating modes for } \\
\text { managing environmental issues related to site operations. }\end{array}$ \\
\hline
\end{tabular}


Table 4

Correspondence between the requirements of the standard ISO14001 and the requirements of the Tuscan Regional Regulation 74/2009.

\begin{tabular}{|c|c|}
\hline ISO 14001:04 & Regional Regulation $74 / \mathrm{r}$ \\
\hline Paragraph 4.3.1 Environmental aspects & Annex I Environmental Review of the industrial area \\
\hline $\begin{array}{l}\text { The organizations shall establish, implement } \\
\text { and maintain a procedure: } \\
\text { a) to identify the environmental aspects of its activities (...) } \\
\text { b) to determine those aspects that have a significant } \\
\text { impact on the environment }\end{array}$ & $\begin{array}{l}\text { The Eco-industrial parks should carry out an environmental } \\
\text { review in order to identify: the quality of the environment, } \\
\text { the significant impact of the industrial sectors located in the industrial park. } \\
\text { The Review should be updated on a three-yearly basis }(\ldots)\end{array}$ \\
\hline Paragraph 4.2 Environmental Policy & Annex II Eco-industrial park Environmental Policy \\
\hline $\begin{array}{l}\text { Top management shall define the } \\
\text { organization's environmental policy... (...) }\end{array}$ & $\begin{array}{l}\text { The Management Body should define an environmental policy of the } \\
\text { area including guiding principles shared by all the stakeholders } \\
\text { involved in the certification process }(\ldots)\end{array}$ \\
\hline Paragraph 4.3.3 Objectives, targets and programmes & Annex III Environmental Improvement Program of the industrial Area \\
\hline $\begin{array}{l}\text { The organization shall establish, } \\
\text { implement environmental objectives }(\ldots)\end{array}$ & $\begin{array}{l}\text { The Management Body should evaluate the program taking into } \\
\text { account the results of the Environmental Review }(\ldots)\end{array}$ \\
\hline
\end{tabular}

Table 5

Example of flexible requirements related to water management included in the Resolution 1245/2009.

\begin{tabular}{|c|c|c|}
\hline No. & Water management & Score \\
\hline 1 & Minimum requirement No. 10 on "Rainwater harvesting/collection and reuse" enhanced by $20 \%$ & 5 \\
\hline 2 & An industrial sewage system & 5 \\
\hline 3 & A purification system for the industrial area & 5 \\
\hline 4 & Separate piping for collecting wastewater/greywater (from washbasins, showers, etc.) to be used as non-drinkable usages & 5 \\
\hline 5 & Filtering ducts in at least $30 \%$ of the area. & 4 \\
\hline 6 & Water for washing cars and machinery (as per minimum requirement No. 19 "Vehicle washing") is supplied by rainwater collected in the area. & 4 \\
\hline 7 & Use of state-of-the-art meters equipped with remote monitoring & 3 \\
\hline 8 & Treatment of wastewater and/or storm water by phytoremediation and/or non-conventional water purification technologies. & 3 \\
\hline 9 & Monitoring and data acquisition regarding leakages in the water supply system & 2 \\
\hline 10 & Low water consumption devices in all offices and tertiary activity buildings. & 2 \\
\hline 11 & Training and awareness-raising on issues related to water consumption and water drainage management (at least once a year). & 1 \\
\hline
\end{tabular}

cooperative approach and are aimed at creating synergies among local actors by coordinating their actions at the territorial level. This approach represents a concrete effort to implement a "holistic vision": if local actors want to obtain a voluntary certification and the related benefits they are "forced" to cooperate in designing local development strategies and policies. These include improved image and consequent attraction of investments, the possibility of obtaining priority public funds from the regional government, along with a shared environmental improvement plan for the area. This is undoubtedly one of the greatest strengths of the standard and it allows other regions (both in Italy and the EU) to follow the path of Tuscany.

Another strength of this approach is the ample sharing of goals by the various regional departments in issuing the certification scheme. This widely-shared agreement means that the Regulation considers exclusive financial incentives for the areas that will get the APEA certification in the future. The Regulation provides for an easier certification process for existing areas than for new construction areas. It is expected that this difference will lead to certification, especially through brown-field redevelopment instead of through the creation of new areas.

The first weakness is linked to the audit that checks whether the criteria required for issuing a certification have been fulfilled. The important role in this audit process played by the municipality where the industrial area is located has been identified as a negative aspect. The municipality is one of the main actors in local management and one of its institutional purposes is the promotion of its own local area by attracting investment capital from outside the area. Its involvement in the certification could lead to a conflict of interests, although the fact that the regional government can carry out spot checks in certified areas partially mitigates this weakness. One way to overcome this could be to create a system of private evaluators, accredited by the regional government, drawing on the methods adopted by similar processes for issuing environmental certifications such as ISO14001 or Regulation 1221/2009 (EMAS).
Another weakness lies in the criteria and indicators included in the standard. The indicators set requirements that are only partially based on the principles of industrial ecology and industrial symbiosis. Considering the minimum criteria, there is a lack of specific indicators that specifically refer to the recovery and/or exchange of energy or materials. There is also a lack of indicators on the economic performance of the area. In the current version, the criteria mainly focus on environmental issues. In a future review and update of the criteria (an activity already provided for by the Regional Regulation), new criteria could be included that focus more on the application of these principles.

This experience can also influence national as well as European eco-industrial policies. At the national level, the certification scheme for EIPs has generated great interest. As Tuscany is seen as one of the most advanced regions in the field of sustainability, the scheme will likely be emulated by other regions or adopted nationally as with previous industrial policy tools such as the EMAS cluster approach (Daddi et al., 2010). At the European level, the experience could contribute to the recent policies adopted by the European Commission in the field of the circular economy (European Commission, 2014).

\subsection{Comparing Chinese and Tuscan standards}

The case described in this paper has no direct parallels in Italy and the EU. However, there are clear similarities with China's National EIP standard, published by the State Environmental Protection Administration (SEPA) ${ }^{1}$ in 2006 (Geng et al., 2009).

\footnotetext{
${ }^{1}$ SEPA has been replaced by Ministry of Environmental Protection (MEP) in 2008. MEP is now in charge in the management of the standard, in any case in this paper
} we will refer to SEPA being the initial subject that approved the criteria. 
Before proceeding with the comparison it is worth analysing the differences between these two contexts. From a physical/productive point of view, Tuscany has specific industrial features such as the large number of SMEs, covering a limited area, while the Chinese industrial areas involve much larger companies covering a larger area. Secondly, China is a fast-growth economy, and economic growth is one of the key objectives of its policies although in the last few years the pursuit of both economic and environmental performances through resource efficiency schemes has become a pillar of national policies. Tuscany is part of a post-industrial country, with an important landscape to protect and with a well developed environmental and safety legislation. Finally, regional governments in Italy are permitted to adopt strong initiatives to manage the region autonomously, while in China this is mainly managed at a national level. Taking into account these differences, the following aims to simply compare the two standards without analysing the effectiveness of them in depth.

Firstly, the objectives of the standard have some similarities. If an industrial zone in China meets the criteria and indicators set by SEPA, it is defined as a "National EIP project." This selection is a way to improve the environmental image of the area and to attract investors. Awarding a qualification of image is quite similar to the issuing of the APEA certificate described above.

In addition, both the Italian and Chinese standards were published by a public body which also manages the qualification process. The regional applicability is rather different, since the SEPA standard applies to all China, while the APEA Regulation only applies to Tuscany. The involvement of a public body in governing the scheme could in certain cases be a guarantee for the credibility of its implementation, or a strong basis for ensuring the resources that are needed to sustain its application.

The first difference in the certification criteria lies in the prerequisites established by the Chinese standard. SEPA states that an industrial area can obtain the National EIP project provided the following circumstances apply:

- in the previous three years there were no environmental incidents in the area that damaged the environment;

- the local environmental quality must meet with the national environmental standards

- tenant companies in the area do not exceed the environmental limits set by permits or public authorities;

- the EIP plan prepared by industrial park managers must be evaluated and approved by SEPA and finally approved by the local government or the Local People's Congress.

In the Tuscan case, there are no pre-requisites for application, and any industrial area in the region can apply for the assessment. One possible justification of the different approaches may lie in the different characteristics of the Italian and Chinese areas. As noted above, the Italian areas have a smaller surface are but a higher number of companies (especially SMEs), while the Chinese areas are in many cases based on a few large companies (FOEN, 2014). This means that the feasibility of verifying the legal compliance of many small companies is very limited and thus more complicated than in the Chinese areas. This is a crucial difference that might even affect the results achieved by the two schemes in terms of environmental improvements. It is too early to judge which is the most effective approach, however further analysis is needed to establish a common method.

SEPA set performance criteria within its standard, and subdivided them into three types of industrial parks: sector-integrated parks, such as development zones where different sectors of industry are situated, and high-tech zones with a concentration of information technology industries and other types of advanced manufacturers; sector-specific parks, including parks with one main sector or anchor tenant, such as chemical parks and steel parks; "venous" parks i.e. resource recovery parks where environmental technology companies and firms make 'green products' (Geng et al., 2009). Tuscany has not broken down the types of activities of the industrial areas. It has provided for two different levels of criteria to be applied in existing areas and in areas of new construction, which is not considered by the Chinese standard. In any case, differentiation according to the "stage" of development of an area seems to be something that can be dealt with through different approaches. A reason for this difference lies in the productive features of the Tuscan areas. They are usually not specialized in one specific sector but combine several industrial and service sectors which prevents sector-specific criteria from being applied.

In the SEPA standard the criteria are divided into four macro categories: 1) economic development, 2) material reduction and recycling, 3) pollution control, 4) park management. Within the second and third macro-categories, SEPA has established performance indicators for various environmental issues such as water discharges, air emissions, waste management, energy consumption, and water consumption. This second level of classification shows that, unlike the Italian standards, SEPA has not established criteria related to urban-planning and infrastructural issues. In fact, the Chinese standard has established a class of criteria relating to economic development, which is not addressed in the Tuscan standard. The choices made by China and Tuscany are not mutually exclusive, thus the two typologies of criteria (urban/infrastructural and economic) could even be integrated simultaneously. The fact that the two schemes have chosen to emphasize one typology rather than the other, is due to the priorities of their policy making: the Chinese context is more influenced by the need to spur economic development, while Tuscany, like many areas in the EU, is under pressure from excessive urbanization and industrialization.

The Tuscan standard includes criteria related to mobility (internal and external) and logistics which are not mentioned in the Chinese standard. Safety is a recurring theme in the Tuscan standard, while it is almost absent in the SEPA. The consideration of safety issues and the additional flexible criteria justify the higher number criteria in Tuscany. Instead, SEPA provides two criteria related to public satisfaction and awareness. These criteria, known as "public satisfaction with local environmental quality" and "public awareness of eco-industrial development" require the industrial parks to carry out a specific questionnaire-based survey and to satisfy specific indicators linked to the results of the survey. The Italian standard on APEA does not include any surveys aimed at investigating the environmental perception of the population. This could be linked to the desire of the regional government not to impose excessive costs on the industrial areas for APEA certification. In any case this could be considered as a weakness of the Tuscan standard and could be improved in future revisions.

Finally, another common element between the two standards is the annual frequency with which the MBs are required to submit a report describing the environmental conditions of the certified industrial area and the improvement targets achieved.

Generally speaking, the Chinese criteria appear more like efficiency indicators required by the local area while the approach of Tuscan standard is more aimed at establishing a list of criteria for the industrial areas that want the certification.

In the next Table 6 the key aspect of Tuscan and Chinese standard are compared.

In China there is another similar initiative although aimed at assessing the performance of EIPs rather than establishing a new policy tool. The "Chinese Circular Economy Evaluation Indicator 
Table 6

Comparison between Tuscan and Chinese standards.

\begin{tabular}{|c|c|c|}
\hline & Tuscan standard & Chinese standard \\
\hline Body issuing the standard & Region Tuscany & $\begin{array}{l}\text { State Environmental Protection Administration (SEPA) } \\
\text { (now managed by Ministry of Environmental Protection-MEP) }\end{array}$ \\
\hline Year & 2009 & 2006 \\
\hline Scope of & Region of Tuscany & Entire State \\
\hline Certification & EEIA certification & National EIP project \\
\hline Pre-requisites for applying & None & Yes \\
\hline Categories of criteria & $\begin{array}{l}\text { Criteria for existing areas - criteria for new areas } \\
\text { Minimum criteria - Flexible criteria }\end{array}$ & Venous parks, sector-integrated parks, sector-specific parks. \\
\hline Class of criteria & a) Urban and planning, b) infrastructural, c) management & $\begin{array}{l}\text { a) Economic development, b) materials reduction and recycling, } \\
\text { c) pollution control, d) park management }\end{array}$ \\
\hline $\begin{array}{l}\text { Number of criteria introduced } \\
\text { in the standard }\end{array}$ & 27 & 21 \\
\hline Unique criteria & Mobility, logistics and safety & Public satisfaction and awareness \\
\hline $\begin{array}{l}\text { Frequency of reports on } \\
\text { environmental state of the area }\end{array}$ & Annual & Annual \\
\hline
\end{tabular}

System" was launched by the National Development and Reform Commission (NDRC) in 2007 and has four categories: resource output, resource consumption, integrated resource utilization, and waste disposal/pollutant emission indicators) applicable at a national as well as regional level (Geng et al., 2012).

The fact that two similar policy initiatives exist in two very different contexts, i.e. China and Italy, is a strong basis and a great opportunity to sustain and prompt the diffusion of this approach to very dissimilar and heterogeneous contexts. This would thus help to develop a common method that could be effectively applied in many other countries both with and outside Europe.

\section{Conclusions}

The paper has different implications for academics, policy makers as well as practitioners.

The overview of the literature and the empirical evidence referring to the national context, highlights the Tuscan experience as a possible trendsetter in using a holistic approach based on voluntary co-operation, bottom-up policy making and, particularly, a third-party certification scheme (connecting sustainability with competitiveness). Like all pioneers, the on-going Tuscan experience still needs to tackle some problems especially regarding the effectiveness of the approach adopted. This will have important implications for future research on IE policies.

To date, no area in Tuscany has yet obtained the APEA certification, however projects are under way in six areas that plan to attain the qualification within the next few years. These leading initiatives involve industrial areas that had already been involved in environmental interventions in pursuit of the principles of industrial ecology before the adoption of Regulation 74/2009. The industrial sectors involved in these initiatives are: tannery, textile, and mechanical. Without real experiences of the application of the standard until the achievement of the certification it is not possible to assess the impact of the standard on environmental and economic performance. Future case studies could investigate these topics involving the first certified Tuscan EIPs. In addition, given the absence of data, it is difficult to determine whether the criteria included in Resolution 1245/2009 are too ambitious or, on the contrary, too flexible and easy to comply with. Firstly, the system may encounter difficulties in getting off the ground and only a few areas will attain certification, which would not involve significant benefits for the entire region. Secondly, the risk is that the funding provided for the certified areas will not be justified by real environmental improvements. Future research could analyse case studies on successful certification experiences, detailing how the criteria were interpreted and applied.

Another crucial implication concerns the outcome of the relatively innovative "holistic" approach. The comparison between the Tuscan and the Chinese case-studies provides some suggestions on the effectiveness of the new "voluntary" and co-operative bottomup approach which has inspired both standards.

Firstly, if the voluntary and co-operative approach is to be effective, it must rely on strong incentives. A credible and effective third-party certification, if accompanied by economic benefits linked to its acquisition, could be essential for its success. This is the work's most important implication for IE-related research and policy. In a "holistic" approach, the incentive could be strictly aimed at enhancing the competitive performance of the whole area, in the form of a third-party voluntary certification. This means that an IEinspired policy, when tested in the field, needs to embrace new instruments and opportunities, such as the voluntary certification, which appears to be working in many other fields of environmental policy (e.g. for management systems, technological innovation, products, etc.), but is being tested for the first time in industrial areas and EIPs.

Secondly, the degree of ambitiousness of the criteria for voluntary certification seems to be key in making it a truly effective policy tool. This has implications on how IE is applied, namely, it means that when holistic initiatives are developed, their targets, programs and requirements must aim for the highest and most outstanding level of the industrial system. This thus guarantees that, the approach can attract and involve the most proactive and innovative actors in the market arena, and that it would really stimulate innovation and competition between industrial areas (within a region) and between SMEs (within the same area). Clearly, all the topics discussed should be confirmed by future research on the assessment of the application of the Tuscan standard.

Finally, the effectiveness and future uptake of this innovative voluntary approach depends on the extent to which the holistic vision is put into practice through the rules and roles involved in the scheme. The institutional framework on which the scheme is based must rely on a strong public actor (e.g. region, municipality) with the sustainable resources and with the wide engagement of the relevant stakeholders, and most importantly the companies located in the area. The catalyst role of the public actor appears to be the only effective and efficient way to engage other potentially interested actors and to mobilize their resources for investments. Only in this way, can a scheme like the Tuscan APEA be used as a policy instrument for sustainability. 


\section{References}

Ammenberg, J., Hjelm, O., 2003. Tracing business and environmental effects of environmental management systems - a study of networking small and medium-sized enterprises using a joint environmental management system. Bus. Strat. Environ. 12 (3), 163-174.

Chertow, M.R., 2000. Industrial symbiosis: literature and taxonomy. Annu. Rev. Energy Environ. 25 (1), 313-337.

Chertow, M.R., Ashton, W.S., Espinosa, J.C., 2008. Industrial symbiosis in Puerto Rico: environmentally related agglomeration economies. Reg. Stud. 42 (10), 1299-1312.

Cohen-Rosenthal, E., 1996. Designing Eco-industrial Parks: the US Experience. UNEP Industry and Environment, pp. 14-18. October-December.

Costa, I., Massard, G., Agarval, A., 2010. Waste management policies for industrial symbiosis development: case studies in European countries. J. Clean. Prod. 18 (8), 815-822.

Daddi, T., Testa, F., Iraldo, F., 2010. A cluster-based approach as an effective way to implement the ECAP (Environmental Compliance Action Program): evidence from some good practices. Local Environ. 15 (1), 73-82.

Daddi, T., Magistrelli, M., Frey, M., Iraldo, F., 2011. Do environmental management systems improve environmental performance? Empirical evidence from Italian companies. Environ. Dev. Sustain. 13 (5), 845-862.

Daddi, T., Tessitore, S., Frey, M., 2012. Eco-innovation and competitiveness in industrial clusters. Int. J. Technol. Manag. 58 (1-2), 49-63.

Daddi, T., Frey, M., Iraldo, F., Nabil, B., 2013. The implementation of an environmental management system in a North-African local public administration: the case of the city council of Marrakech (Morocco). J. Environ. Plan. Manag. 54 (6), $813-832$.

Eilering, J.A.M., Vermeulen, W.J.V., 2004. Eco-industrial parks: toward industrial symbiosis and utility sharing in practice. Progr. Ind. Ecol. Int. J. 1 (1-2-3), $245-270$.

European Commission, 2014. Communication from the Commission to the European Parliament, the Council, the European Economic and Social Committee and the Committee of the Regions "Towards a Circular Economy: a Zero Waste Programme for Europe/* COM/2014/0398 Final".

FOEN, 2014. International Survey on Eco-innovation Parks. Federal Department of Environment, Transport, Energy and Communications, Bern.

Geng, Y., Côté, R., 2003. Environmental management systems at the industrial park level in China. Environ. Manag. 31 (6), 784-794.

Geng, Y., Doberstein, B., 2008. Developing the circular economy in China: challenges and opportunities for achieving 'leapfrog development'. Int. J. Sustain. Dev. World Ecol. 15 (3), 231-239.

Geng, Y., Zhang, P., Côté, R.P., Fujita, T., 2009. Assessment of the national ecoindustrial park standard for promoting industrial symbiosis in China. J. Ind. Ecol. 13 (1), 15-26.

Geng, Y., Fu, J., Sarkis, J., Xue, B., 2012. Towards a national circular economy indicator system in China: an evaluation and critical analysis. J. Clean. Prod. 23, 216-224.

Gibbs, D., Deutz, P., 2007. Reflections on implementing industrial ecology through eco-industrial park development. J. Clean. Prod. 15 (17), 1683-1695.

Heeres, R.R., Vermeulen, W.J.V., de Walle, F.B., 2004. Eco-industrial park initiatives in the USA and the Netherlands: first lessons. J. Clean. Prod. 12 (8-10), 985-995.

Hendricks, B., Giannini-Spohn, F., 2003. The role of government in eco-industrial development. In: Cohen- Rosenthal, E., Musnikow, J. (Eds.), Eco-industrial Strategies: Unleashing Synergy between Economic Development and the Environment. Greenleaf, Sheffield, pp. 68-88.

Iraldo, F., Testa, F., Frey, M., 2009. Is an environmental management system able to influence environmental and competitive? The case of the eco-management and audit scheme (EMAS) in the European Union. J. Clean. Prod. 17 (18), $1444-1452$.

IRPET, Unioncamere Toscana, 2013. La situazione economica della Toscana. Florence, available from: http://www.irpet.it/storage/eventoallegato/1397_ Rapporto\%20generale\%202014.pdf.

Korhonen, J., Strachan, P.A., 2004. Towards progress in industrial ecology. Prog. Ind. Ecol. 1 (1-3), 1-23.

Korhonen, J., Von Malmborg, F., Strachan, P.A., Ehrenfeld, J.R., 2004. Management and policy aspects of industrial ecology: an emerging research agenda. Bus. Strat. Environ. 13 (5), 289-305.
Lehtoranta, S., Nissinen, A., Mattila, T., Melanen, M., 2011. Industrial symbiosis and the policy instruments of sustainable consumption and production. J. Clean. Prod. 19 (17-18), 1865-1875.

Lombardi, D.R., Laybourn, P., 2012. Redefining industrial symbiosis. J. Ind. Ecol. 16 (1), 28-37.

Lombardi, D.R., Lyons, D., Shi, H., Agarwal, A., 2012. Industrial symbiosis. J. Ind. Ecol. $16(1), 2-7$.

Martin, S.A., Weitz, K.A., Cushman, R.A., Sharma, A., Lindrooth, R.C., 1996. Eco-industrial Parks: a Case Study and Analysis of Economic, Environmental, Technical and Regulatory Issues. Office of Policy, Planning and Evaluation. USEPA Washington DC.

Mirata, M., 2004. Experiences from early stages of a national industrial symbiosis programme in the UK: determinants and coordination challenges. J. Clean. Prod. 12 (8-10), 967-983.

Niutanen, V., Korhonen, J., 2003. Towards a regional management system - waste management scenarios in the Satakunta Region, Finland. Int. J. Environ. Technol. Manag. 3 (2), 131-156.

Opoku, H.N., 2004. Policy implications of industrial ecology conceptions. Bus. Strat. Environ. 13 (5), 320-333.

Park, H.S., Rene, E.R., Choi, S.M., Chiu, A.S.F., 2008. Strategies for sustainable development of industrial park in Ulsan, South Korea - from spontaneous evolution to systematic expansion of industrial symbiosis. J. Environ. Manag. 87 (1), 1-13.

Regione Toscana, 2009a. Regolamento Regionale n. 74/r in materia di Aree produttive ecologicamente attrezzate (APEA) in attuazione dell'articolo 18 della legge regionale 10 dicembre 1998, n. 87 (Regional Regulation n. 74/r in the matter of Ecologically Equipped Industrial Areas (APEA) implementing article 18 of the regional law 10 December 1998, n.87). Firenze: Regione Toscana.

Regione Toscana, 2009b. Deliberazione della Giunta Regionale n. 1245 Approvazione del documento "Criteri per la definizione delle prestazioni ambientali delle Aree produttive ecologicamente attrezzate (APEA)" (Resolution of Regional Government n.1245 Approval of the document "Criteria for the identification of environmental performances of Ecologically Equipped Industrial Areas (APEA)"). Firenze: Regione Toscana.

Regione Toscana, 2014. "Piano Ambientale ed Energetico Regionale (PAER)" Giunta Regionale il 23 dicembre 2013, in conformità alla l.r. 44/2013 ed al relativo regolamento di attuazione approvato con DPGR 23 giugno 2001, n.24/R (Tuscany region. "Regional Energy and Environmental Plan (PAER)" Regional Board 23 dicembre 2013, pursuant to LR 44/2013 corresponding to implementing regulations adopted by DPGR June 23, 2001, n. 24/R).

Sanches Pereira, A., Vilela, A., Rutkowski, E.W., 2009. Industrial ecology as strategic tool for environmental policy-making process in Brazil. In: 2nd Internationa Workshop - Advances in Cleaner Production, May 20th-22nd, São Paulo Brazil.

Shi, H., Chertow, M. Song Y, 2010. Developing country experience with ecoindustrial parks: a case study of the Tianjin economic-technological development area in China. J. Clean. Prod. 18 (3), 191-199.

Snaekin, J.P., Korhonen, J., 2002. Industrial ecology in the North Karelia region in Finland-scenarios for heating energy supply. Int. J. Sustain. Dev. World Ecol. 9 (1), 9-21.

Tudor, T., Adam, E., Bates, M., 2007. Drivers and limitations for the successful development and functioning of EIPs (eco-industrial parks): a literature review. Ecol. Econ. 61 (2-3), 199-207.

Van Berkel, R., Fujita, T., Hashimoto, S., Geng, Y., 2009. Industrial and urban symbiosis in Japan: analysis of the Eco. Town program 1997-2006. J. Environ. Manag. 90 (12), 1544-1556.

Von Malmborg, F., 2004. Networking for knowledge transfer: towards an understanding of local authority roles in regional industrial ecosystem management. Bus. Strat. Environ. 13 (5), 334-346.

Welford, R., 2004. Commentary: regional environmental management systems: lessons and challenges for industrial ecology research. Prog. Ind. Ecol. Int. J. 1 (1-3), 286-291.

Yu, C., Davis, C., Dijkema, G.P.J., 2014. Understanding the evolution of industrial symbiosis research. A bibliometric and network analysis (1997-2012). J. Ind. Ecol. 18 (2), 280-293.

Zhang a, L., Yuan, Z., Bi, J., Zhang a, B., Liu a, B., 2010. Eco-industrial parks: national pilot practices in China. J. Clean. Prod. 18 (5), 504-509.

Zhu, Q., Cote, R.P., 2004. Integrating green supply chain management into an embryonic eco-industrial development: a case study of the Guitang group. J. Clean. Prod. 12 (8-10), 1025-1035. 